\title{
Quichua of Imbabura: A Brief Phonetic Sketch of Fricatives
}

\author{
Jesus Toapanta \\ Dept. of Linguistics, Pontificia Universidad Católica del Ecuador. \\ 12 de Octubre 1076 y Roca, Quito-Ecuador \\ Tel: 593-2299-1700Ｅ-mail: jltoapanta@puce.edu.ec \\ Marleen Haboud (Corresponding Author) \\ Dept. of Linguistics, Pontificia Universidad Católica del Ecuador. \\ 12 de Octubre 1076 y Roca, Quito-Ecuador
}

Tel: 593-2299-1700Ｅ-mail: MHABOUD@puce.edu.ec

Received: February 20, 2012 Accepted: February 26, 2010 Published: June 1, 2012

doi:10.5296/ijl.v4i2.1474 URL: http://dx.doi.org/10.5296/ijl.v4i2.1474

\begin{abstract}
Quechua is considered to be the language of the Incas. This civilization ruled during approximately 1430 to 1530 . Their Empire was called Tahuantinsuyo and covered the areas currently occupied by Ecuador, Peru, Bolivia, north and the central region of Chile and northeast Argentina; at present, it is in Ecuador, Peru and Bolivia where Quechua still remains vigorous, at least in the sense of the number of speakers.

Quechua dialects are very diverse and vary significantly in features such as voicing, frication, glotalization, aspiration, vowel sounds, and in the absence or presence of certain sounds. This paper presents phonetic data regarding the fricative and affricate sounds of the Quechua language; it provides current data of a language dialect spoken in the province of Imbabura- Ecuador, most commonly known as Quichua. The data were elicited from people belonging to the Otavalo indigenous community.
\end{abstract}

Keywords: Quichua, Quechua, Endangered languages, Indigenous language, Language of the Incas 


\section{Background}

\subsection{The Language of the Incas}

By 1537, the Inca Empire covered the areas currently occupied by Ecuador, Perú, Bolivia, central and north of Chile, and northeast of Argentina. This region was called Tahuantinsuyo and was divided into four sub areas or "Suyos" (Chinchay-suyo, Colla-suyo, Antisuyo and Cunti-suyo). The expansion of the Inca Empire began in the central highland region of Perú around 1438-1471, and it was carried out by three Inca Emperors: Yupanqui (Pachacutic), Tupac Yupanqui, and Huaina Capac.

Before the Spanish conquest over the Incas, the words Quechua or Quichua were not used for any specific linguistic designation; instead, phrases such as "the general language", "the language of the Inca" or "the language of Cuzco" were used to refer to the language that was most broadly spread in the region. Mannheim (1985) argued that the language strictly speaking is runa simi "human speech"; however, it seems that the Spaniards made a mistake interpreting qheswa simi "valley speech"; thus, what the Spanish used to refer to as "the general Language" became qheswa. (p. 482)

At present, the word Quechua is used as an umbrella term which includes all dialects, and therefore the particular dialect spoken in Ecuador which is more commonly referred to as Quichua. Both Gary Parker and Alfredo Torero, although with different nomenclature, have divided Quechua into two major varieties; the variety spoken in the central area of Perú and the variety spoken peripherally. This latter includes the sub-varieties spoken in Colombia, Ecuador, northern and southern Perú, Bolivia and Argentina (Mannheim, 1985, pp. 489-90).

\section{The Qhichua Language}

\subsection{Quichua in Ecuador}

There are two hypotheses about the origin of Quichua in Ecuador. The first claims that Quichua was brought from Perú during the expansion of the Inca Empire; and the second claims that Quichua was spoken in Ecuador before the arrival of the Incas. In this regard, Parker (1972) concluded that when the Incas arrived in the central and north region of Perú and Ecuador, Quechua was already spoken by the majority of the population (p. 115).

The Quechua language, at present, is spoken in Colombia, Ecuador, Perú, Bolivia, Chile, Argentina and Brazil; however, it is in Ecuador, Perú, and Bolivia where Quechua has become a strong indigenous language. Particularly in Ecuador, out of the 12 local indigenous languages, Quichua is spread along the Highlands and some areas of the Amazon region. Approximately 3,000,000 people in the Highlands and 60,000 people in the Amazon region use the language (CONAIE, 2006). Haboud (1998), based on a survey of 2,841 people carried out in nine provinces of the highlands, found that that $73 \%$ of the interviewees had Quichua as their mother tongue, 24\% had Spanish as their native tongue and 3\% had both Spanish and Quichua exposure since early childhood (p.72). 


\section{Macrothink}

International Journal of Linguistics

ISSN 1948-5425

2012, Vol. 4, No. 2

The Quichua population is organized into communities. They are divided into nationalities in the highlands (See Table 1 below \& Map 1 in the appendix). In the Amazon region, Quichua is spoken in Napo, Pastaza, Sucumbios and Orellana (CODENPE, 2006).

Table 1. Quichua Nationalities

\begin{tabular}{|l|l|l|}
\hline $\begin{array}{l}\text { Ecuadorian Provinces in the } \\
\text { Highlands }\end{array}$ & Nationalities (CODENPE, 2006) & $\begin{array}{l}\text { Cerrón-Palomino } \\
(\mathbf{2 0 0 3})\end{array}$ \\
\hline Imbabura & Karanki, Natabuela, and Otavalo & Caranquis \\
\hline Pichincha & Kitukara & Quitus \\
\hline Pichincha, Imbabura and Napo & Kayambi & \\
\hline Cotopaxi & Panzaleo & Panzaleos \\
\hline Tungurahua & Chibuleo and Salasaca & \\
\hline Tungurahua and Chimborazo & & Puruhaes \\
\hline Chimborazo & Puruha & \\
\hline Bolivar & Waranka & Chimbus \\
\hline Cañar and Azuay & Kañari & \\
\hline Azuay and Loja & & Cañaries \\
\hline Loja and Zamora Chinchipe & Saraguro & \\
\hline Loja & & Paltas \\
\hline
\end{tabular}

The Quichua speaking population is divided into 12 nationalities. This is rather consistent with the 7 ethnic groups reported by Cerrón-Palomino (2003).

\subsection{Dialects}

Orr (1962) reported dialectal differences of Quichua in Ecuador; data were gathered from eight different areas and compared to the dialect spoken in Puyo Pongo. She named the dialects of the highland as A, B, C, D, E and F; and the dialects of the Amazon region or lowlands as $\mathrm{G}$ and H. (pp. 75-77)

Parker (1969) presented a diagram showing the relationship among the various Quichua dialects spoken in Ecuador. (p.157) 


\section{Proto-Ecuadorian}

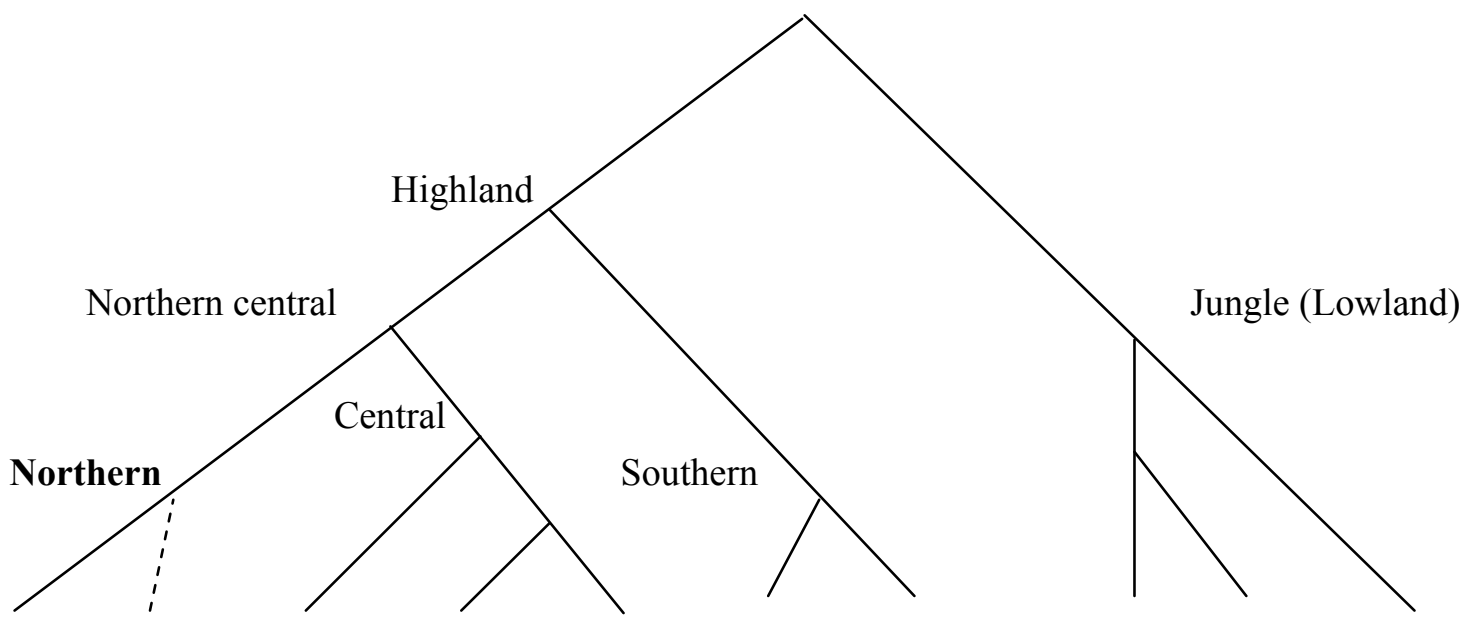

Agato Calderon Colta Dulucate Caliate Caragura Azuay Bobonaza Tena Limoncocha

Stark (1985) divided Quichua in two major dialects: Ecuadorian A (spoken in Pichincha, Cotopaxi and Tungurahua), and Ecuadorian B (spoken in Imbabura, Cañar, Azuay and Loja) (pp. 446-460). Although Stark (1985) suggested that there might exist more Quichua dialects in the Amazon region, she identified three. To the north, the Limoncocha dialect morphologically similar to the Quichua spoken in Imbabura; in the central Oriente, the Tena dialect similar to the central region of the Highlands; and to the South, Bobonaza dialect phonologically and lexically similar to the Quechua spoken in the Peruvian Montaña (pp. 182-183).

Knapp (1991) carried out an ethno-linguistic study based on the national census of 1950. He shows some areas of Quichua concentrations in Ecuador; one isolated area to the north which includes the current provinces of Imbabura and Pichincha, and other areas to the south which include the highland provinces from Cotopaxi to Azuay. In the overlapping of Imbabura and Pichincha provinces, he mentions three cities: Otavalo, Cotacachi and Cayambe (pp. 17-19). (See Map 2 in the Appendix).

\subsection{Sounds}

Cordero (1892) mentioned that, in the Quichua dialect spoken in Azuay, the consonants of Quichua are: b, c, ch, d, g, h, j, l, ll, m, n, n, p, q, r, s, sh, t, y, z, zh; and that this particular dialect lacks the consonantal sounds $[\mathrm{f}, \mathrm{k}, \mathrm{v}$, and $\mathrm{x}]$. He said that the [ $\mathrm{f}]$ is totally unknown by the Indians, and even in Spanish they cannot pronounce it; the [ $\mathrm{k}$ ] sound is perfectly represented by [ $\mathrm{c}$ ]; the [ $\mathrm{v}$ ] sound is represented by [ b ]; and the [ $\mathrm{x}]$ sound is represented by the combination of [ gs ]. The [sh] sound is similar to the English sound [ $\int$ ]; the [zh] sound is compatible with the French sound [ j] as in 'jadis' and 'toujours'; and the [z] is similar to the Spanish [z] but rather softer; and, the sound [g] is less hard than the [c] sound. Explicitly, he said that Ecuadorian Quichua is different from Peruvian and Bolivian in the sense of pronouncing the sounds more softly; therefore, words like cuyac, tucyana and pucyu are represented as cuyag 'el que ama', tugyana 'reventar' and pugyu 'fuente'(pp. XXI-XXII). 
Orr (1962) reports the existence of twenty seven phonemes in the Quichua of Puyo Pongo in eastern Ecuador. She describes three vowels / i /, / a /, and / u /; and two semivowels (bilabial / w / and alveopalatal / y /); nasals occurring at three points of articulation (bilabial / $\mathrm{m} /$, alveolar / $\mathrm{n} /$ and alveopalatal / $\tilde{\mathrm{n}} /$ ); liquids occurring at three points of articulation (alveolar flap / r /, alveolar lateral / 1 / and alveopalatal lateral / $1^{\mathrm{j}} /$ ); spirants occurring at three points of articulation (alveolar / s /, alveopalatal / $\breve{\mathrm{s}} /$ and glottal / h /); and voiced and voiceless stops at five points of articulation (bilabial / p / \& / b /, alveolar / t / \& / d /, alveolar affricated / c / \& / $\mathrm{z} /$, alveopalatal affricated / $\check{c} / \& / \mathrm{j} /$, and velar / k / \& / g /). She also included one group of stops called 'palatal' (bilabial / $\mathrm{p}^{\mathrm{j}} /$, alveolar / $\mathrm{t}^{\mathrm{j}} /$ and velar $/ \mathrm{k}^{\mathrm{j}} /$ ) (pp. 60-63).

Parker (1969) presented a phonological system which includes contrastive segments due to borrowings in both Highland and Jungle. He basically said that the voiced stops [ b ], [ d ], and [ $\mathrm{g}$ ] already existed as allophones, and the phones [ $\mathrm{z}$ ] and [ $\check{\mathrm{z}}$ ] have been coined into this phonological system from other native languages. (pp. 159-169)

Stark and Muysken (1977) pointed out that most of the sounds of Quichua spoken in the Highlands take the same pronunciation as the alphabetical letters of Spanish; however, they pointed out some differences (pp. 365-366):

The [ c'], [ ch'], [ p'], [ qu'], and [ t'] are aspirated (e.g. c'ari 'hombre'; ch'uca 'baba'; p'iti 'pedazo'; qu'ihua 'hierba'; t'uñi 'derrumbe'). The [ c'] sound is similar to the first sound of the Spanish word 'casa'; the [ ch'] is similar to the first sound of the Spanish word 'chico'; the [ $\mathrm{p}$ '] sound is similar to the first sound of the Spanish word 'pico'; the [ qu'] is similar to the first sound of the Spanish word 'Quito'; and the [ t'] is similar to the first sound of the Spanish word 'tipo'; however, all this Quichua sounds are more aspirated than the usual Spanish sounds. The [ $\mathrm{z}$ ] is a voiced alveolar sibilant (e.g. zugzug 'puñado'). It contrasts with the voiceless alveolar sibilant [ $\mathrm{s}]$. The [ $\mathrm{sh}$ ] is a voiceless alveopalatal sibilant (e.g. mashna 'cuanto'); it is similar to the first sound of the English word 'ship'. The [ ts ] is a voiceless alveolar oclusiva (e.g. tsala 'flaco'); it is similar to the first sound of the German word 'zeit'.

In the Northern provinces of the Ecuadorian Highland, the [ 11 ] sound is an alveopalatal voiced sibilant, and not an alveopalatal voiced lateral like in the Southern provinces of the Ecuadorian Highland. In the province of Azuay, this sound oscillates in the middle. The [ $\mathrm{zh}$ ] of the southern provinces of the Ecuadorian Highland is a voiced alveopalatal oclusiva (e.g. zhru 'aspero'); it is pronounced the same as the Northern Ecuadorian highland [ 11 ] or like the $[\mathrm{z}$ ] sound of the English word 'azure'. At the beginning or end of a Word, the $[r]$ is a re-sonorous voiced alveopalatal (e.g. randina 'comprar'; yahuar 'sangre'); it is similar to the intervocalic sound of the Spanish Word 'perro'. In other positions the [ $r$ ] is a voiced vibrant and pronounced as the intervocalic sound of the Spanish word 'pero' (e.g. carana 'dar de comer'). 


\section{Methodology}

The data contain sounds of isolated words elicited in the northern province of Imbabura, San Jose de Quichinche. The parish is located in Otavalo (See Map 1 in the Appendix).

\subsection{Subjects}

Three participants were recruited for the study; they were bilingual Quichua-Spanish speakers. Two of the informants did not have formal instruction, and the other had completed primary school; the three of them acquired Quichua as their native language, that is, they learned it naturally from their parents. They were a family and lived together. The mother, 65 years old, said she communicates with her family and her friends in Quichua; the father, 62 years old, said he communicates with his family and friends in Quichua and Spanish; and the daughter, 24 years old, said she communicates only with her mother in Quichua but when she talks to her children she uses Spanish. They all used Quichua as a means of communication every day. The three of them were born in Quichinche-Imbabura and had resided there for 24 years; before that time they lived somewhere else but it has always been in Quichinche-Imbabura. They identified themselves as Otavalos. They made a living by manufacturing indigenous clothing. They travel throughout Ecuador selling their textiles.

\subsection{Materials}

A questionnaire used to elicit background information from the participants; the 100 words used in Orr's study (1962: 60-63), and the 200 Swadesh words; and, a digital voice recorder to record the data.

\subsection{Procedures}

The informants were visited in their house (Quichinche-Imbabura), and they were informed about the project and process of data collection. During this first meeting (12/06/2007), the three of them participated collectively, and it was feasible to collect Orr's word list. In general, they were asked to translate orally Spanish words into Quichua and Quichua words into Spanish. During the second meeting (12/16/2007), only the father and the mother participated, and it was possible to collect the 200 Swadesh word list.

\section{Results}

The results are reported below. Data are presented under the label: Quichua, Imbabura. This is followed by a Spanish translation and Cordero's data.

\subsection{The alveolar voiceless fricative [ $s$ ]}

This sound [ s ] occurs word initial, medial, and final; only one occurrence was registered word final: 'siete' [kan3is] (See Table 2). 
Table 2.

\begin{tabular}{|l|l|l|}
\hline Quichua, Imbabura & Spanish & Quichua, Cordero \\
\hline$[$ s $]$ & & {$[$ s $]$} \\
\hline$[$ sirana $]$ & Coser & {$[$ sirana $]$} \\
\hline$[$ sisa $]$ & Flor & {$[$ sisa $]$} \\
\hline$[$ sapi $]$ & Raíz & {$[$ sapi $]$} \\
\hline$[$ suni $]$ & Largo & {$[$ suni $]$} \\
\hline$[$ usa $]$ & Piojo & {$[$ usa $]$} \\
\hline$[$ kaspi $]$ & Palo, tronco & {$[$ caspi $]$} \\
\hline
\end{tabular}

Its voiced counterpart sound [ z ] was registered in medial position: 'fino, delgado' [hayzi]; and Cordero transcribed it as 'residuo, afrecho' [jamchi]. Moya (1981) argued that the alveolar fricative varies depending on the region; so regional alternations will exhibit: [hamzi], [hamtsi] and [hamt $\left.\int i\right]$ 'afrecho' (p. 172).

\subsection{The voiced palatal fricative [ 3]}

Cordero (1892), when referring to the Quichua dialects spoken in Azuay, southern highland Ecuador, described a sound similar to the palatal lateral approximant $[\Lambda]$ in terms of the Spanish double '1'; he transcribed this sound as [11 ] (pp. XXI-XXII). On the other hand, Orr (1962) transcribed the palatal lateral sound of Puyo Pongo with a little ' $y$ ' next to ' 1 ', [ $\left.1^{\mathrm{j}}\right]$. (p. 60). I think they both meant to describe a palatal lateral sound [ $\Lambda$ ]. In the data taken from Imbabura, this sound in word initial is not palatal lateral, but voiced palatal fricative (See Table $3 \& 4$ ).

Table 3.

\begin{tabular}{|l|l|l|}
\hline Quichua, Imbabura & Spanish & Quichua, Cordero \\
\hline [ 3 ] & & {$[$ ll ] } \\
\hline$[3 \mathrm{uki}]$ & Izquierda & {$[$ [lluqui] } \\
\hline$\left[3 \mathrm{a} \int \mathrm{a}\right]$ & Pesado & {$[$ llashag $]$} \\
\hline$[3 \mathrm{u} 3 \mathrm{u}]$ & Tierno & {$[1 \mathrm{lullu}]$} \\
\hline
\end{tabular}


Table 4

\begin{tabular}{|l|l|l|}
\hline Quichua, Imbabura & Spanish & Quichua, Orr \\
\hline [ 3 ] & & {$\left[1^{\mathrm{j}}\right]$} \\
\hline$[$ 3antu $]$ & Dia sombrio & {$\left[1^{\mathrm{j}}\right.$ antu $]$} \\
\hline$[$ 3agta $]$ & Villa & {$\left[1^{\mathrm{j}}\right.$ akta $]$} \\
\hline [3ugSina $]$ & Salir & {$\left[1^{\mathrm{j}}\right.$ ukšina $]$} \\
\hline [3apina $]$ & Pisar, aplastar & {$\left[1^{\mathrm{j}}\right.$ apina $]$} \\
\hline
\end{tabular}

Such observation was made by Stark and Muysken (1977) when referring to the northern provinces of the highland. They said that the [ 11 ] sound is an alveopalatal voiced sibilant, and not an alveopalatal voiced lateral as in the Southern provinces of the Ecuadorian Highland (p. 365). This is not only true for word initial but also for word medial positions (See Table 5 \& 6).

Table 5.

\begin{tabular}{|l|l|l|}
\hline Quichua, Imbabura & Spanish & Quichua, Cordero \\
\hline$[$ 3 $]$ & & {$[$ ll $]$} \\
\hline$[\mathrm{ki3u}]$ & Amarillo & {$[$ quillu] } \\
\hline$[\mathrm{mi3ai}]$ & Maldad & {$[$ millay $]$} \\
\hline$[$ tu3u $]$ & Hueso & {$[$ tullu] } \\
\hline$[$ pug3ana $]$ & Jugar $(\mathrm{v})$ & {$[$ pugllana $]$} \\
\hline
\end{tabular}

Table 6.

\begin{tabular}{|l|l|l|}
\hline Quichua, Imbabura & Spanish & Quichua, Orr \\
\hline$[$ 3 $]$ & {$\left[1^{\mathrm{j}}\right]$} \\
\hline$[\mathrm{tu3u}]$ & Hueso & {$\left[\mathrm{tu} 1^{\mathrm{j}} \mathrm{u}\right]$} \\
\hline$[$ ag3ana $]$ & Escoger & {$\left[\right.$ an $1^{\mathrm{j}}$ ana $]$} \\
\hline$[$ ki3a $]$ & Luna, mes & {$\left[\mathrm{ki} 1^{\mathrm{j}} \mathrm{a}\right]$} \\
\hline
\end{tabular}

While Cordero (1892) described two different sounds, there is only one equivalent sound in the province of Imbabura. He described the sounds [ 11 ] and [ zh ] for the Quichua spoken in Azuay, which are compatible with a palatal lateral $[\kappa]$ and a voiced palatal 
fricative [ 3 ] respectively; however, in the province of Imbabura, these two sounds seem to have merged into [ 3 ] as shown by the examples above and the following (See Table 7).

Table 7.

\begin{tabular}{|l|l|l|}
\hline Quichua, Imbabura & Spanish & Quichua, Cordero \\
\hline$[$ 3 $]$ & & {$[$ zh $]$} \\
\hline$[\mathrm{t}$ uy3uli $]$ & Intestinos & {$[$ chunzhulli] } \\
\hline$[$ puy3a $]$ & Día & {$[$ punzha $]$} \\
\hline
\end{tabular}

In this regard, Stark and Muysken (1977) mentioned that the [ zh ] of the southern provinces of the Ecuadorian highland is a voiced alveopalatal oclusiva pronounced the same as the northern Ecuadorian highland [ 11 ] or as the letter ' $z$ ' in the English word 'azure'(p. 366).

In sum, what for Cordero and Orr is a palatal lateral [ $\wedge$ ], for the Quichua dialect of Imbabura, this is a voiced palatal fricative [ 3 ]. In addition, while Cordero described two different sounds: [ $\mathrm{K}$ ] and [ 3 ], the Quichua dialect of Imbabura exhibits only one [ 3 ].

\subsection{The voiceless palatal fricative [ $\left.\int\right]$}

This palatal sound occurs word initial and word medial. Only one elicited word in the data registered this sound word final: [ nukapa $\int$ ] ' $I$ also'. The voiceless palatal fricative $[S]$ is really consistent with the description of Cordero (1892) and Orr (1962). Stark and Muysken (1977) described it as a voiceless alveopalatal sibilant. This sound is the same as the first sound of the English word 'she' (See Table 8).

Table 8.

\begin{tabular}{|l|l|l|}
\hline Quichua, Imbabura & Spanish & Quichua, Cordero \\
\hline$[\quad$ S $]$ & & {$[$ sh $]$} \\
\hline$\left[\int\right.$ imi $]$ & Boca & {$[$ shimi $]$} \\
\hline$[$ Jungu $]$ & Corazón & {$[$ shungu $]$} \\
\hline$\left[\int \mathrm{u}\right]$ & Uno & {$[$ shug $]$} \\
\hline$\left[\mathrm{mu} \int \mathrm{u}\right]$ & Nuevo & {$[$ mushug $]$} \\
\hline$\left[\mathrm{wa} \int \mathrm{a}\right]$ & Espalda & {$[$ huasha $]$} \\
\hline$\left[\mathrm{i} \int \mathrm{kai}\right]$ & Dos & {$[$ ishcay $]$} \\
\hline
\end{tabular}

\subsection{The voiced palatal affricate [ $\mathrm{d} 3]$}

Orr (1962) said that when followed by nasals, the alveopalatal affricate is voiced in the Quichua dialect of Imbabura, and voiceless in the other Quichua dialects of the highlands. She mentioned, however, that there are a few words that have the voiced sound in all

dialects. She described the voiced affricate with this symbol: [ j ] , which is compatible with voiced palatal affricate $[\mathrm{d} 3]$ (p. 62).

In the province of Imbabura, this sound was not registered. Nevertheless, it was a voiced 
palatal fricative sound [ 3 ] encountered in these same environments (See Table 9).

Table 9.

\begin{tabular}{|c|c|c|}
\hline Quichua, Imbabura & Spanish & Quichua, Orr \\
\hline [ 3 ] & & {$[\quad \check{j}]$} \\
\hline$[$ [in3i $]$ & Duro, fuerza & [sinji] \\
\hline [kan3is] & Siete & [kanjis] \\
\hline [pun3a] & Dia & [punǰa] \\
\hline [tSun3uli] & Intestinos & [čunjuli] \\
\hline
\end{tabular}

Given these data, it appears that in the Quichua dialect of Imbabura, the phones [ 3 ], [ d3 ], and $[\Lambda]$ have merged into the sound [ 3$]$.

\subsection{The voiceless palatal affricate [ $\left.t \int\right]$}

Moya (1982) referred to the [ ts ] sound as voiceless palatal, and said that although this sound is not very frequent, it tends to coexist with [ $\left.\mathrm{t} \int\right]$ (p. 185). Also, Potosi (2004) mentions that the phone $\left[\mathrm{t} \int\right]$ is realized as [ ts ] in the central and north areas of Ecuador (p. 7).

Stark and Muysken (1977) also included the phone [ ts ] in their dictionary. They described it as voiceless alveolar and said that this sound is similar to the first sound of the German word 'zeit' (p. 366). In the Quichua Dialect of Imbabura, this sound [ ts ] was registered in the word for 'one hundred' [patsag].

The description of the phone [ ts ] in the word [patsag] is consistent with the description given by Stark and Muysken. However, Cordero (1892) transcribed the word for 'one hundred' as [pasag] (p. 169).

The voiceless palatal affricate $\left[\mathrm{t} \int\right]$ was registered in word initial and word medial (See Table 10).

Table 10.

\begin{tabular}{|l|l|l|}
\hline Quichua, Imbabura & Spanish & Quichua, Cordero \\
\hline$\left[\mathbf{t} \int\right]$ & & {$[$ ch $]$} \\
\hline$\left[\mathrm{t} \int\right.$ usku $]$ & Cuatro & {$[$ chuscu $]$} \\
\hline$\left[\mathrm{t} \int\right.$ un3uli $]$ & Intestinos & {$[$ chunzhulli] } \\
\hline$\left[\mathrm{t} \int \mathrm{a} g a\right]$ & Pierna & {$[$ changa $]$} \\
\hline$\left[\right.$ ait $\left.\int \mathrm{a}\right]$ & Carne & {$[$ aycha $]$} \\
\hline$\left[\right.$ pit $\left.\int \mathrm{a}\right]$ & Cinco & {$[$ pichca $]$} \\
\hline$\left[\right.$ akt $\left.\int \mathrm{a}\right]$ & Cabello & {$[$ agcha $]$} \\
\hline
\end{tabular}

\subsection{The voiceless glottal fricative [ $h]$}

Orr (1962) categorized this phone [ $\mathrm{h}$ ] as glottal spirant, and said that it occurs in two 
allophonic forms: velar fricative $[\mathrm{x}]$ when preceding $\left[\mathrm{l}^{\mathrm{j}}\right]$ and utterance final; and $[\mathrm{h}]$ elsewhere (p. 61). This phone [ $\mathrm{h}$ ] was registered word initial and medial (See Table 11).

Table 11.

\begin{tabular}{|l|l|l|}
\hline Quichua, Imbabura & Spanish & Quichua, Cordero \\
\hline$[\mathbf{h}]$ & & {$[\mathbf{h}]-[\mathbf{j}]$} \\
\hline$\left[\right.$ humbi $\left.\int \mathrm{ca}\right]$ & Sudor & {$[$ humbi $]$} \\
\hline$[$ haku $]$ & Vamos & {$[$ jacu $]$} \\
\hline$\left[\right.$ huku $\left.\int k a\right]($ male $)$ & Mojado & {$[$ jucushca $]$} \\
\hline$[$ uhuna $]$ & Toser & {$[$ ujuna $]$} \\
\hline$\left[\mathrm{kit} \int \mathrm{i}(\mathrm{h} / \mathrm{x}) \mathrm{i}\right]$ & Angosto & {$[$ quichqui $]$} \\
\hline$[$ mutixina $]$ & Oler & {$[$ mutquina $]$} \\
\hline$\left[\right.$ tax $\left.\int a n a\right]$ & Lavar ropa & {$[$ tagshana $]$} \\
\hline
\end{tabular}

Orr (1962) said that the velar stop / k / in Imbabura and Pichincha is realized only with aspiration; thus, the word 'kiwa' (weed) is pronounced as [hiwa] instead of [kiwa] or [khiwa] as in other areas. Some examples which exhibit this pattern were registered; it seems that a process of weakening has taken place: $\mathrm{k}>\mathrm{h}$ (See Table 12).

Table 12 .

\begin{tabular}{|l|l|l|}
\hline Quichua, Imbabura & Spanish & Quichua, Cordero \\
\hline$[$ h $]$ & & {$[$ c $]$} \\
\hline$[$ hakuna $]$ & Frotar & {$[$ cacuna $]$} \\
\hline$[$ huru $]$ & Gusano, insecto & {$[$ curu $]$} \\
\hline$[$ ha3u $]$ & Lengua & {$[$ callu $]$} \\
\hline$[$ hari $]$ & Macho & {$[$ cari $]$} \\
\hline
\end{tabular}

\subsection{Voiceless bilabial fricative $[\phi]$}

The voiceless bilabial stop / $\mathrm{p} /$ has the variant sound $[\phi]$, voiceless bilabial fricative. Cordero (1892) pointed out that the Quichua dialect of the southern province of Azuay lacked this sound $[\phi]$ (XXI-XXII). Also, Moya (1981) in her phonological system of Quichua spoken in Quito mentioned that this sound is an allophone of / $\mathrm{p} /$; her examples among others were: [puyu - фuyu] 'nube', and [wairapukuna - wairaфukuna] 'el viento sopla' (p. 172).

In the Quichua spoken in Imbabura, this sound [ $\phi]$ occurs word initial and word medial; and it does seem to be an alternation of the voiceless bilabial stop / p / (See Table 13). 
Table 13.

\begin{tabular}{|c|c|c|}
\hline Quichua, Imbabura & Spanish & Quichua, Cordero \\
\hline$[\phi]$ & & {$[\mathbf{p}]$} \\
\hline 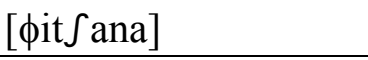 & Barrer & [pichana] \\
\hline$[\phi u j u]$ & Nube & [puyu] \\
\hline [фukuna] & Soplar & [pucuna] \\
\hline [фa jga $]$ & Hoja & [panga] \\
\hline [uфiana] & Tomar & [upiana] \\
\hline [ut $\left.\int \mathrm{u} \phi \mathrm{a}\right]$ & Ceniza & [uchupa] \\
\hline
\end{tabular}

Orr (1962) mentioned that word initial / p / is pronounced with friction in the dialects spoken in the northern provinces of Ecuador (Imbabura) rather than with aspiration as in the other dialects of the Ecuadorian highland. It may probably be that this sound $[\phi]$ is in the process of becoming a phoneme considering the fact that the informant corrected me when I pronounce a certain word with the sound [p] (p. 76).

\subsection{The alveolar fricative ' $r$ ' $[\check{r}]$}

In the province of Imbabura, the sound [ $r$ ] is realized as a flap [ $r$ ] and as a fricative [ $\breve{r}$ ]. Stark and Muysken (1977) pointed out that at the beginning or end of a word, the $[r$ ] sound is a re-sonorous voiced alveopalatal sound which is similar to the intervocalic sound of the Spanish Word 'perro'. They added that in other positions this sound [ $r$ ] has a voiced vibrant sound and is pronounced as the intervocalic sound of the Spanish word 'pero' (p. 365).

The data show [ $r$ ] being realized as a flap [ $r$ ] word medial, and as a fricative [ $\check{r}$ ] word initial (See Table 14 and 15).

Table 14.

\begin{tabular}{|l|l|l|}
\hline Quichua, Imbabura & Spanish & Quichua, Cordero \\
\hline$[\boldsymbol{r}]$ & & {$[\mathbf{r}]$} \\
\hline$[\mathrm{ki} r \mathrm{c}]$ & Árbol & {$[$ quiru $]$} \\
\hline$\left[\mathrm{t} \int \mathrm{r} i\right]$ & Frio & {$[$ chiri $]$} \\
\hline$[$ huru $]$ & Gusano & {$[$ curu $]$} \\
\hline$[$ ari $]$ & Si & {$[$ ari $]$} \\
\hline$[$ urpi $]$ & Tórtola & {$[$ urpi $]$} \\
\hline$[$ warmi $]$ & Mujer & {$[$ huarmi $]$} \\
\hline
\end{tabular}


Table 15.

\begin{tabular}{|l|l|l|}
\hline Quichua, Imbabura & Spanish & Quichua, Cordero \\
\hline$/ \check{\text { r̆ } /}$ & & $/ \mathbf{r} /$ \\
\hline$[\check{\text { raku }}]$ & Grueso & {$[$ racu $]$} \\
\hline$[\check{\text { ricuna }]}$ & Mirar & {$[$ ricuna $]$} \\
\hline$[\check{\text { r̆undu }]}$ & Granizo & {$[$ rundu $]$} \\
\hline$[\check{\text { rij3i }]}$ & Oreja & {$[$ ringri-rinrri $]$} \\
\hline
\end{tabular}

Orr (1962) made a distinction between the [ $r$ ] in initial position; she said that all word initial r's are retroflexed in the highlands and flapped in the lowlands (p. 77). In Imbabura, this sound $[\mathrm{r}$ ] was realized as a fricative word final as well: 'Sangre' [jawař].

\section{Comments}

The voiceless alveolar fricative sound [ s ] occurs word initial and medial, only one occurrence was registered word final: 'siete' [kay3is]. Its voiced counterpart sound [ z ] was registered in medial position in the word: 'fino, delgado' [hayzi].

What for other dialects is a palatal lateral, for the Quichua dialect of Imbabura, this sound is a voiced palatal fricative [ 3 ]. And while Cordero described two different sounds: [ 11 ] compatible to $[\kappa]$, and [ zh ] compatible to [ 3 ], the Imbabura Quichua dialect exhibits only [ 3 ]. The voiced palatal fricative sound [ 3 ] occurs word initial and medial. Moreover, the voiced palatal affricate sound [ d3 ] was not registered; instead, [ 3 ] was found. So, in Imbabura Quichua, the sounds [ 3 ], [ d3 ], and [ $\Lambda$ ] may seem to have merged into [ 3 ]; however, to claim this, a more thorough analysis and more data are necessary.

The voiceless palatal fricative sound $[S]$ occurs word initial and word medial. Only one word in the data exhibited this sound word final: [nukapa $\left.\int\right]$ 'I also'. The voiceless palatal affricate sound [ $\mathrm{t} S$ ] was registered word initial and medial; in addition, the affricate sound [ $\mathrm{ts}$ ] was registered in the word: 'one hundred' [patsag]. When Moya (1982) referred to the sound [ ts ], she said that this phone is not very frequent and tends to coexist with [ $\left.\mathrm{t} \int\right]$ (p. 185).

The voiceless glottal fricative sound [ $\mathrm{h}$ ] occurs word initial and medial, and seems to alternate freely with the voiceless velar fricative sound $[\mathrm{x}]$.

The voiceless bilabial fricative [ $\phi$ ] occurs word initial and word medial. Although neither complementary distribution nor free variation was found with [ $p]$, it may possibly be that

$[\phi]$ is in the process of phonemization; again, for such a claim more data is necessary.

The voiced alveolar liquid sound [ $r$ ] is realized as a flap [ $r$ ] and as a fricative [ $\breve{\mathrm{r}}$ ]. Word medial is realized as a flap, and word initial as a fricative; only one word exhibited [ $\breve{\mathrm{r}}$ ] word final: 'Sangre' [jawař].

Table 16 below summarizes the fricative sounds found in the data collected in the Quichua dialect spoken in the parish of San Jose de Quichinche. 
Table 16.

\begin{tabular}{|c|c|c|c|c|c|c|}
\hline \multicolumn{2}{|c|}{ Stops } & Bilabial & Alveolar & Palatal & Velar & Glottal \\
\hline \multirow{2}{*}{ Nasal } & voiceless & & & & & \\
\cline { 2 - 7 } & voiced & & & & & \\
\hline \multirow{2}{*}{ Fricatives } & voiceless & {$[\phi]$} & {$[\mathrm{s}]$} & {$[\delta]$} & & {$[\mathrm{h}]$} \\
\hline \multirow{2}{*}{ Affricates } & voiced & & & {$[3]$} & & \\
\hline \multirow{2}{*}{ Liquids } & Lateral & & & {$[\mathrm{t} \delta]$} & & \\
\cline { 2 - 8 } & $\mathrm{r} *$ & & {$[r] \&[\check{r}]$} & & & \\
\hline
\end{tabular}

$\mathrm{r}^{*}$ is realized as a flap $[r]$ and as a fricative $[\breve{\mathrm{r}}]$.

\section{References}

Cerrón-Palomino, R. (2003). Lingüistica Quechua (2nd ed.). Cuzco-Perú: Centro de Estudios Regionales Andinos Bartolomé de las Casas.

CODENPE. (2006). Nacionalidades y puebles Indígenas del Ecuador. [Online] Available: http://www.codenpe.prg.ec (November 01, 2006).

CONAIE. (2006). Las Nacionalidades indígenas en el Ecuador: Nuestro Proceso Organizativo (2nd ed.). Quito-Ecuador: Ediciones Abya-Yala, (1989). 284. [Online] Available: http://www.conaie.nativeweb.org (November 02, 2006).

Cordero, L. (1892). Diccionario Quichua-Castellano y Castellano-Quichua (4th ed.). QuitoEcuador: Corporación Editora Nacional.

Haboud, M. (2004). Quichua Language vitality: an Ecuadorian perspective. International Journal of the Sociology of language. 167, 69-81. http://dx.doi.org/10.1515/ijsl.2004.022

Knapp, G. (1991). Geografía Quichua de la Sierra del Ecuador: Núcleos, Dominios y Esferas (3rd ed.). Quito-Ecuador: Ediciones ABYA-YALA.

Mannheim, B. (1985). Southern Peruvian Quechua. In Harriet E. Menelis Klein and L. R. Stark. (Eds.), South American Indian Languages: Retrospect and Prospect (pp. 481- 515). Austin: University of Texas Press.

Moya, R. (1981). Simbolismo y Ritual en el Ecuador Andino: El Quichua en el Español de Quito. Otavalo-Ecuador: Editorial Gallocapitán, IOA.

Orr, C. (1962). Ecuador Quichua Phonology. In B. Elson (Ed.), Studies in Ecuadorian Indian 
languages: I. (1 ${ }^{\text {st }}$ ed.), (pp. 60-77). University of Oklahoma: SIL.

Parker, G. (1969). Comparative Quechua Phonology and Grammar IV: The evolution of Quechua A. In Working papers in Linguistics, issue 9, pp. 149-204: University of Hawaii.

Parker, G. (1972). Falacias y verdades acerca del quechua. In A. Escobar (Ed.), El Reto del multilingualismo en el Perú (pp. 107-122). Lima-Perú: Instituto de estudios Peruanos.

Potosi, F. (2004). Quri Qinti mushukyachishka shimiyukpanka: Diccionario qichwa actualizado Quri Qinti. Quito Ecuador: Ediciones Qichwakunamanta yachaykuna Wasi, IAEQ.

Stark, L. R. (1985). Ecuadorian Highland Quechua: History and current Status. In Harriet E. Menelis Klein and L. R. Stark (Eds.), South American Indian Languages: Retrospect and Prospect (pp. 443-480). Austin: University of Texas Press.

Stark, L. R. (1985). Indigenous Languages of Lowland Ecuador: History and current Status. In Harriet E. Menelis Klein and L. R. Stark (Eds.), South American Indian Languages: Retrospect and Prospect (pp. 157-193.). Austin: University of Texas Press.

Stark, L. R., \& Muysken, P.C. (1977). Diccionario Español-Quichua y Quichua-Español. Guayaquil-Ecuador: Archivo Histórico del Guayas, Museo del Banco Central del Ecuador. 
Appendix

Map 1 Political Division of Highland Ecuador, 2008.

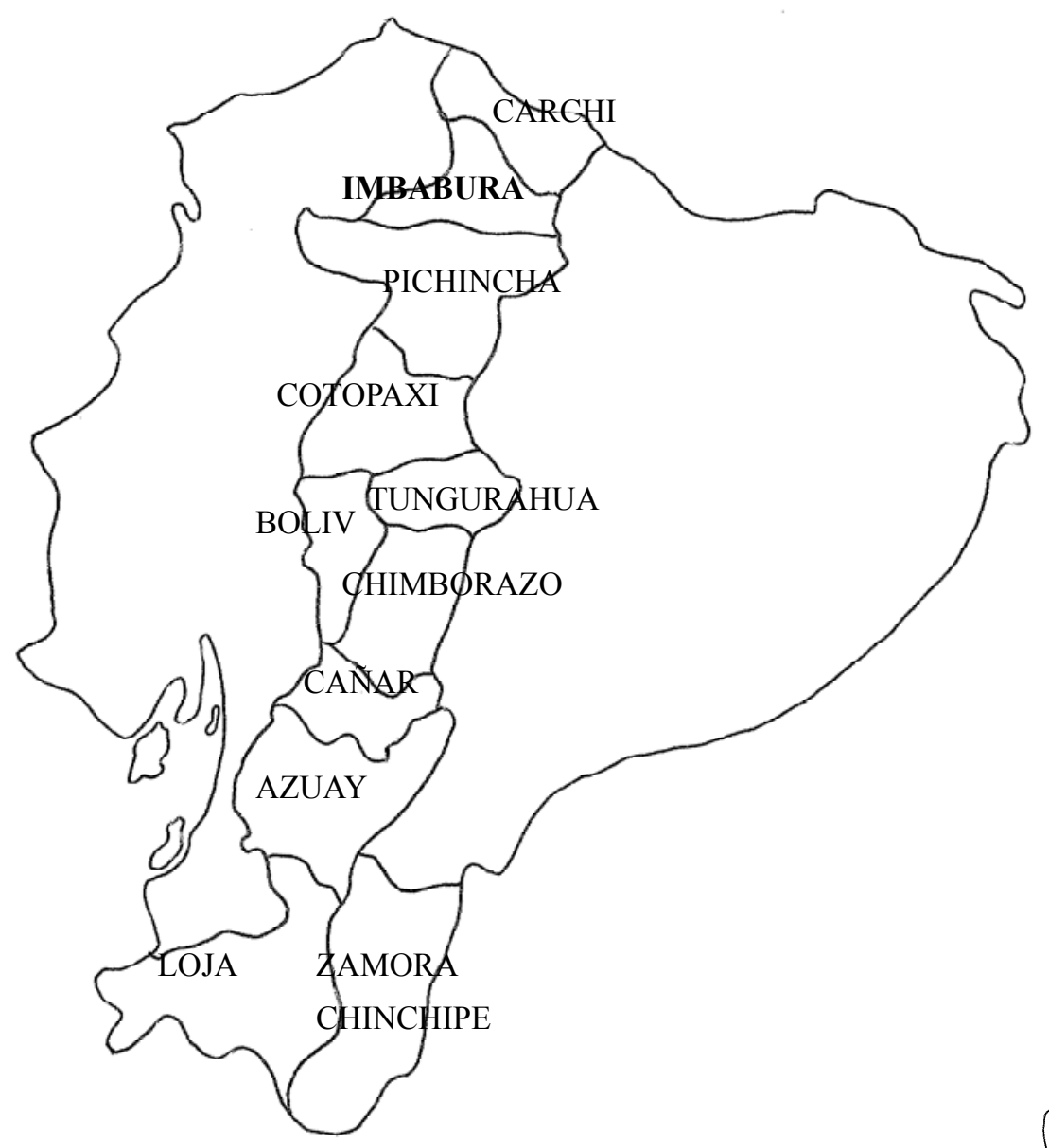

IMBABURA, QUICHINCHE.

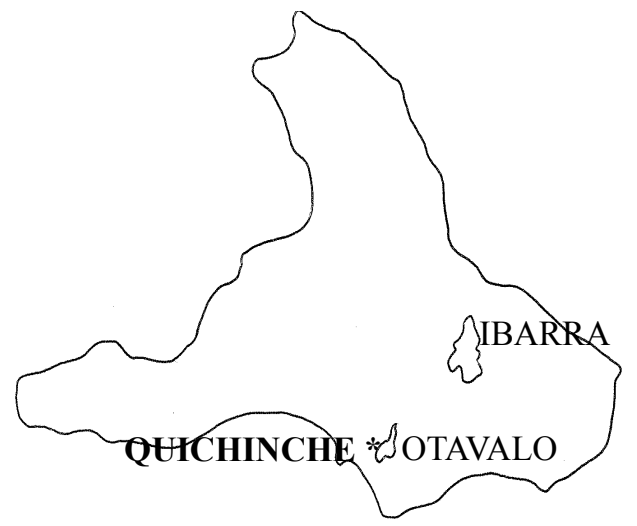




\section{Macrothink

Map 2 Concentrations of the Quichua Culture in the Highlands

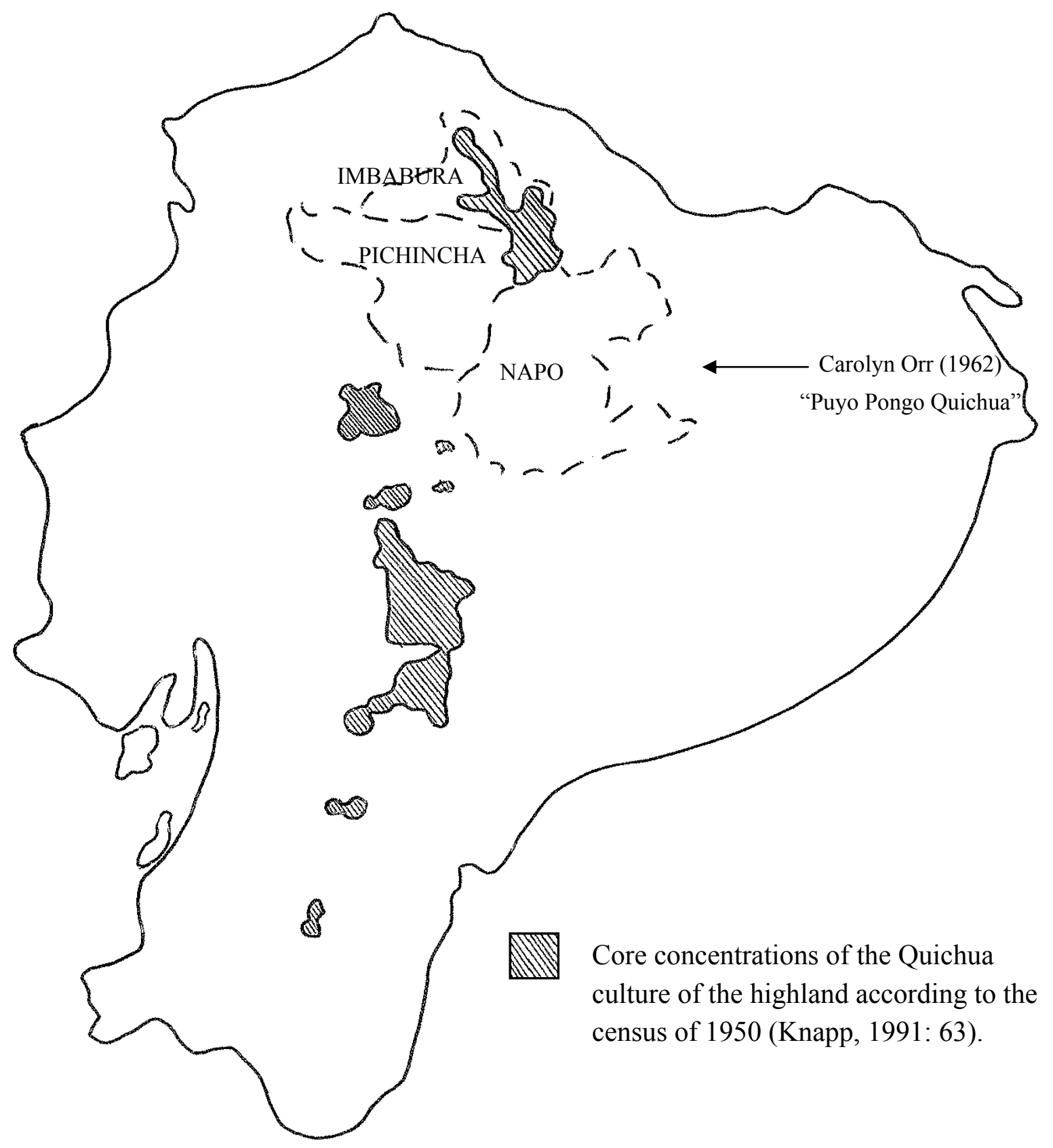

